\title{
PENINGKATAN MUTU KINERJA GURU MELALUI SUPERVISI AKADEMIK DI SDN 2 PASIR PANJANG SEMESTER I TAHUN PELAJARAN 2019/2020
}

\author{
Ncreasing The Quality Of Teacher Performance Through Academic Supervision At SDN 2 Pasir \\ Panjang Semester I The 2019/2020 Academic Year
}

\section{SUPRIYANTO, S.Pd SD,}

SDN 2 Pasir Panjang

*Kalimantan Tengah, Indonesia.

\begin{abstract}
Abstrak
Data penelitian tindakan sekolah yang diperoleh dari Hasil penilaian Mutu Berdasarkan observasi pendahuluan dan wawancara langsung dengan kepala guru-guru SDN 2 Pasir Panjang memiliki kinerja yang kurang baik. guru-guru SDN 2 Pasir Panjang belum memiliki kedisiplinan yang tinggi yang ditujukan kepada seluruh warga sekolah. Dengan fasilitas yang kurang memadai SDN 2 Pasir Panjang jadi kurang mampu bersaing dengan sekolah lain. Tujuan penelitian ini untuk mengetahui: I. supervisi akademik di SDN 2 Pasir Panjang tahun 2019. 2. sejauh mana supervisi akademik dalam meningkatkan mutu kinerja guru di SDN 2 Pasir Panjang tahun 2019. Oleh karenanya peneliti hendak meningkatkan mutu kinerja guru SDN 2 Pasir Panjang melalui supervisi akademik. Penelitian ini merupakan penelitian tindakan sekolah (School Action Research).Penelitian ini akan dilaksanakan di SDN 2 Pasir Panjang. Penelitian akan dilakukan pada semester ganjil tahun 2019. subjek penelitian adalah guru yang ada di sekolah ini, baik yang sudah pegawai negeri sipil maupun yang masih wiyata bakti. Pengumpulan data dalam penelitian ini menggunakan tiga teknik yaitu wawncara, observasi dan dokumentasi.

Data penelitian tindakan sekolah yang diperoleh dari Hasil penilaian mutu kinerja guru pada pra siklus, hasilnya adalah mutu kinerja guru rendah. $\mathrm{Hal}$ ini di tunjukkan dengan adanya perolehan skor rata-rata hasil penilaian siklus I yaitu 57,5 , oleh karenanya perlu peningkatan ke skor yang lebih tinggi lagi agar mencapai skor maksimal.
\end{abstract}

\section{Kata Kunci:}

Mutu Kinerja Guru,

Supervisi Akademik

\section{Keywords:}

Teacher Performance Quality,

Academic Supervision

\section{Accepted \\ Juli 2021}

Published

Agustus 2021
School action research data obtained from quality assessment results. Based on preliminary observations and direct interviews with the principal teachers of SDN 2 Pasir Panjang, the performance was not good. the teachers of SDN 2 Pasir Panjang do not yet have high discipline aimed at all school members. With inadequate facilities, SDN 2 Pasir Panjang is less able to compete with other schools. The purpose of this study was to find out: I. academic supervision at SDN 2 Pasir Panjang in 2019. 2. To what extent did academic supervision improve the quality of teacher performance at SDN 2 Pasir Panjang in 2019. Therefore, researchers want to improve the quality of teacher performance at SDN 2 Pasir Panjang through academic supervision. This research is a school action research (School Action Research). This research will be conducted at SDN 2 Pasir Panjang. The research will be conducted in the odd semester of 2019. The research subjects are teachers in this school, both those who are civil servants and those who are still serving. Data collection in this study used three techniques, namely interviews, observation and documentation.

School action research data obtained from the results of the assessment of the quality of teacher performance in the pre-cycle, the result is the quality of teacher performance is low. This is indicated by the acquisition of the average score of the first cycle assessment, which is 57.5, therefore it is necessary to increase to a higher score in order to achieve the maximum score. is Open Access article under the CC-BY-SA License (http://creativecommons.org/licenses/by-sa/4.0/).

\section{A. Latar Belakang Masalah}

Pendidikan memiliki peranan penting dalam kehidupan kita, baik untuk saat ini maupun masa mendatang. Pendidikan sebagai suatu proses untuk menuju perbaikan, penguatan, dan pengembangan segala potensi yang dimiliki peserta didik agar dapat berkembang secara optimal.
Dalam mencapai tujuan pendidikan tersebut, diperlukan seorang guru sebagai agen pembelajaran bagi peserta didik. Guru merupakan orang yang bertanggungjawab dalam mengajar dan mendidik peserta didik di sekolah. Guru memiliki peranan yang sangat penting dalam menentukan keberhasilan pendidikan untuk menghasilkan output yang berkualitas. Oleh karena itu, guru harus melaksanakan tugas dan 
tanggungjawabnya dengan maksimal sehingga dapat mencapai tujuan yang diharapkan.

Guru dalam menjalankan tugasnya dituntut memiliki kompetensikompetensi tertentu. Kompetensi adalah seperangkat pengetahuan, keterampilan, dan perilaku yang harus dimiliki, dihayati, dan dikuasai oleh guru atau dosen dalam melaksanakan tugas keprofesionalan.

Mengingat pentingnya keterlibatan guru dalam keberhasilan penyelenggaraan pendidikan, kinerja guru perlu dikembangkan secara terus menerus. Kinerja merupakan gambaran tentang hasil kerja seseorang yang berkaitan dengan tugas yang diembannya, dan didasarkan pada tanggungjawab profesional yang dimiliki seseorang. Guru dalam melaksanakan tugasnya, didasarkan pada standar kinerja guru. Standar kinerja merupakan patokan dalam mengadakan pertanggungjawaban terhadap segala hal yang telah dikerjakan.

Standar kinerja guru berhubungan langsung dengan kualitas guru dalam menjalankan tugasnya seperti: (I) bekerja sama dengan siswa secara individual, (2) persiapan dan perencanaan pembelajaran, (3) pendayagunaan media pembelajaran, (4) melibatkan siswa dalam berbagai pengalaman belajar, dan (5) kepemimpinan yang aktif dari guru.

Namun pada kenyataannya di lapangan, guru tidak dengan mudah menjalankan tugasnya karena dihadapkan dengan berbagai masalah yang timbul dalam kehidupannya, kurang adanya persiapan yang matang serta fasilitas yang kurang mendukung untuk melaksanakan tugasnya sebagai seorang pendidik. Hal ini akan memunculkan masalah terhadap kinerja guru yang tidak produktif, padahal guru dituntut untuk bekerja secara profesional.

Kinerja memiliki posisi penting dalam manajemen dan organisasi. Karena, keberhasilan dalam melakukan pekerjaan sangat ditentukan oleh kinerja. Hal ini berarti, jika seseorang bekerja dalam organisasi, kinerjanya merupakan serangkaian perilaku dan kegiatan secara individual sesuai dengan harapan atau tujuan organisasi. Rendahnya kinerja guru tentu dapat menurunkan mutu pendidikan dan menghambat tercapainya visi di suatu sekolah. Sekolah yang seperti itu tidak akan mampu menghasilkan lulusan yang unggul dan memiliki daya saing di kancah global seperti sekarang ini. Oleh karena itu kinerja harus dikelola dengan baik dan dijaga agar tidak mengalami penurunan. Bahkan, seharusnya selalu diperhatikan agar mengalami peningkatan secara terus menerus.

Upaya untuk mengembangkan dan meningkatkan kinerja guru pada dasarnya merupakan suatu kebutuhan organisasi yang tidak pernah berakhir. Hal ini disebabkan pengembangan dan peningkatan kinerja tidak hanya dilakukan jika terjadi kesenjangan antara kinerja aktual dengan kinerja yang diharapkan, tetapi juga pengembangan dan peningkatan tersebut harus tetap dilakukan meskipun tidak terjadi kesenjangan. Sebab, perubahan lingkungan eksternal organisasi yang sangat cepat dewasa ini akan mendorong pada meningkatnya tuntutan yang lebih tinggi pada organisasi.

Berdasarkan observasi pendahuluan dan wawancara langsung dengan kepala guru-guru SDN 2 Pasir Panjang memiliki kinerja yang kurang baik. guruguru SDN 2 Pasir Panjang belum memiliki kedisiplinan yang tinggi yang ditujukan kepada seluruh warga sekolah. Dengan fasilitas yang kurang memadai SDN 2 Pasir Panjang jadi kurang mampu bersaing dengan sekolah lain. Adapun upaya-upaya yang dilakukan guru dalam meningkatkan kinerjanya yakni dengan mengikuti pelatihan-pelatihan seperti in-house training (IHT), diklat, workshop, dan seminar baik yang diselenggarakan secara internal maupun eksternal. Dengan mengikuti pelatihan-pelatihan tersebut, guru memperoleh wawasan dan ilmu pengetahuan yang dapat menunjang kinerja guru sebagai pendidik. Walaupun guru SDN 2 Pasir Panjang secara umum kurang memiliki kinerja yang baik, namun guru-guru terus berupaya untuk menjaga dan meningkatkan kinerjanya. Apalagi pada era globalisasi seperti sekarang ini, guru dituntut untuk terus meningkatkan mutu kinerjanya dalam menjalankan tugas sebagai pendidik.

Bagi penulis, ini merupakan penelitian yang sangat menarik untuk dikaji. Guru merupakan faktor penentu dalam keberhasilan penyelenggaraan pendidikan. Karena guru memiliki peranan penting dalam penyelenggaraan pendidikan, maka guru harus selalu meningkatkan mutu kinerja sebagai seorang pendidik. Mutu kinerja guru perlu ditingkatkan agar dapat mencapai tujuan pendidikan yang diharapkan. Selain itu, kinerja guru yang bermutu tentu berkontribusi terhadap kemajuan lembaga pendidikan.

Oleh karenanya peneliti hendak meningkatkan mutu kinerja guru SDN 2 Pasir Panjang melalui supervisi akademik. Supervisi akademik adalah serangkaian kegiatan membantu guru mengembangkan kemampuannya mengelola proses pembelajaranuntuk mencapai tujuan pembelajaran (Daresh, 1989, Glickman, et al;2007). Supervisi akademik tidak terlepas dari penilaian kinerja guru dalam mengelola pembelajaran. Sergiovanni (1987) menegaskanbahwa refleksi praktis penilaian kinerja guru dalam supervisi.

Tujuan supervisi akademik adalah (I) membantu guru mengembangkan ompetensinya, (2).mengembangkan kurikulum,dan (3) mengembangkan kelompok kerja guru, dan membimbing penelitian tindakan kelas (PTK).Supervisi akademik merupakan salah satu (fungsi mendasar (essential function) dalam keseluruhan program sekolah. Hasil supervisi akademik berfungsi sebagai sumber informasi bagi pengembanganprofesionalisme guru.

Berdasarkan uraian latar belakang di atas maka penulis tertarik untuk mengadakan penelitian yang akan dituangkan dalam sebuah bentuk tulisan PTS dengan judul "PENINGKATAN MUTU KINERJA GURU MELALUI SUPERVISI AKADEMIK DI SDN 2 PASIR PANJANG SEMESTER I TAHUN PELAJARAN 2019/2020" 


\section{A. Kajian Teori}

\section{A) Mutu Kinerja Guru}

\section{Pengertian Kinerja Guru}

Menurut Mangkunegara (200I:67) kinerja adalah hasil kerja secara kualitas dan kuantitas yang dicapai oleh seorang dalam melaksanakan tugasnya sesuai dengan tanggung jawab yang diberikan kepadanya. Tinggi rendahnya kinerja pekerja berkaitan erat dengan sistem pemberian penghargaan yang diterapkan oleh lembaga/organisasi tempat mereka bekerja.

Pemberian penghargaan yang tidak tepat dapat berpengaruh terhadap peningkatan kinerja seseorang. Berkaitan erat dengan kinerja guru di dalam melaksanakan tugasnya sehari-hari sehingga dalam melaksanakan tugasnya guru perlu memiliki tiga kemampuan dasar agar kinerjanya tercapai sebagai berikut:

a. Kemampuan pribadi meliputi hal-hal yang bersifat fisik seperti tampang, suara, mata atau pandangan, kesehatan, pakaian, pendengaran, dan hal yang bersifat psikis seperti humor, ramah, intelek, sabar, sopan, rajin, kreatif, kepercayaan diri, optimis, kritis, obyektif, dan rasional;

b. Kemampuan sosial antara lain bersifat terbuka, disiplin, memiliki dedikasi, tanggung jawab, suka menolong, bersifat membangun, tertib, bersifat adil, pemaaf, jujur, demokratis, dan cinta anak didik;

c. Kemampuan profesional sebagaimana dirumuskan oleh P3G yang meliputi 10 kemampuan profesional guru yaitu: menguasai bidang studi dalam kurikulum sekolah dan menguasai bahan pendalaman/aplikasi bidang studi, mengelola program belajar mengajar, mengelola kelas, menggunakan media dan sumber, menguasai landasanlandasankependidikan, mengelola interaksi belajar mengajar, menilai prestasi siswa untuk kepentingan pendidikan, mengenal fungsi dan program bimbingan penyuluhan, mengenal dan menyelenggarakan administrasi sekolah, memahami prinsip dan menafsirkan hasil-hasil penelitian pendidikan guna keperluan mengajar menurut.

Kinerja seseorang dapat ditingkatkan bila ada kesesuaian antara pekerjaan dengan keahliannya, begitu pula halnya dengan penempatan guru pada bidang tugasnya. Menempatkan guru sesuai dengan keahliannya secara mutlak harus dilakukan. Bila guru diberikan tugas tidak sesuai dengan keahliannya akan berakibat menurunnya cara kerja dan hasil pekerjaan mereka, juga akan menimbulkan rasa tidak puas pada diri mereka. Rasa kecewa akan menghambat perkembangan moral kerja guru.

Faktor-faktor yang mempengaruhi kinerja Guru antara lain :

a. Faktor personal/individual, meliputi unsur pengetahuan, keterampilan (skill), kemampuan, kepercayaan diri, motivasi, dan komitmen yang dimiliki oleh tiap individu guru

b. Faktor kepemimpinan, meliputi aspek kualitas manajer dan team leader dalam memberikan dorongan, semangat, arahan dan dukungan kerja pada guru

c. Faktor tim, meliputi kualitas dukungan dan semangat yang diberikan oleh rekan dalam satu tim, kepercayaan terhadap sesama anggota tim, kekompakan dan keeratan anggota tim d. Faktor sistem, meliputi sistem kerja, fasilitas kerja yang diberikan oleh pimpinan sekolah, proses organisasi (sekolah) dan kultur kerja dalam organisasi (sekolah).

Upaya yang dapat dilaksanakan untuk meningkatkan kinerja guru antara lain antara lain: I) menerima kehadiran baru dengan baik; 2) memberi tugas mengajar baru sesuai dengan bidang dan kompetensi yang dikuasi oleh guru baru; 3) membentuk dan melaksanakan kelompok kerja guru bidang studi dan musyawarah guru bidang studi sejenis (MGMP) sebagai wadah bagi guru untuk berdiskusi merencanakan masalah dan memecahkan masalah yang terjadi di kelas; 4) melakukan supervisi administrasi dan akedemik terhadap guru baru sebagai bahan perbaikan dan menentukan kebijakan; 5) melukukan pembinaan baik bersifat administratif, klinis, maupun karier guru baru; 6) memberi kesempatan pada guru baru untuk mengikuti pelatihan baik yang dilaksanakan di sekolah, kabupaten, propinsi maupun pada tingkat nasional; 7) memberi reward (penghargaan) pada guru yang berprestasidan memberikan hukuman pada guru yang malas dan bermasalah; 8) memberi tugas tambahan pada guru baru; 9) membentuk ikatan keluarga di sekolah masing-masing dengan pertemuan dilaksanakan di rumah anggota ikatan keluarga.

Menilai kinerja guru di sekolah bukan sebuah hal yang sederhana. Perlu sebuah komunikasi yang baik di dalam sekolah sendiri untuk membuat sebuah standar penilaian yang baik. Standar penilaian kinerja guru yang baik tidak muncul begitu saja. Perlu diupayakan kesepakatan dari pihak yang akan menilai (kepala sekolah) dan guru yang akan dinilai. Dengan demikian tercapai saling pengertian bahwa proses penilaian kinerja guru, sama sekali bukan untuk mencari-cari kesalahan tetapi semata-mata untuk peningkatan kinerja agar sekolah dapat berjalan lebih baik lagi dalam prakteknya. Serta bagaimana agar sekolah dapat membantu guru agar lebih baik lagi dalam melakukan pembelajaran dikelas.

\section{Upaya Meningkatkan Kinerja Guru}

Guru adalah salah satu komponen pendidikan yang memegang peran penting dalam keberhasilan pendidikan, guru diharapkan mampu memainkan peran sebagai guru yang ideal. Masyarakat mengharapkan agar 'guru' merupakan sosok yang dapat 'digugu' dan 'ditiru'. Guru juga merupakan salah satu tokoh yang harus dijunjung tinggi, yaitu: 'guru, ratu, wongatua karo' (Tilaar, 2004: II). Pemerintah sering melakukan berbagai upaya peningkatan kualitas guru, antara lain melalui pelatihan, seminar, dan lokakarya, bahkan melalui pendidikan formal, dengan menyekolahkan guru pada tingkat yang lebih tinggi. Kendatipun pada pelaksanaannya masih jauh dari harapan. Banyak faktor yang mempengaruhi kinerja guru, tetapi permasalahan dalam makalah ini difokuskan pada peran kepemimpinan kepala sekolah, pemberian kompensasi, kinerja guru, dan pengembangan Sumber Daya Guru (SDM). 


\section{B) Supervisi Akademik}

\section{Pengertian Supervisi Akademik}

Glickman (198I), mendefinisikan supervisi akademik adalah serangkaian kegiatan membantu guru mengembangkan kemampuannya mengelola proses pembelajaran demi pencapaian tujuan pembelajaran. Supervisi akademik merupakan upaya membantu guruguru mengembangkan kemampuannya mencapai tujuan pembelajaran. (Daresh, 1989). Dengan demikian, berarti, esensi supervisi akademik itu sama sekali bukan menilai unjuk kerja guru dalam mengelola proses pembelajaran, melainkan membantu guru mengembangkan kemampuan profesionalismenya.

Meskipun demikian, supervisi akademik tidak bisa terlepas dari penilaian unjuk kerja guru dalam mengelola pembelajaran. Apabila di atas dikatakan, bahwa supervisi akademik merupakan serangkaian kegiatan membantu guru mengembangkan kemampuannya mengelola proses pembelajaran, maka menilai unjuk kerja guru dalam mengelola proses pembelajaran merupakan salah satu kegiatan yang tidak bisa dihindarkan prosesnya (Sergiovanni, 1987). Penilaian unjuk kerja guru dalam mengelola proses pembelajaran sebagai suatu proses pemberian estimasi kualitas unjuk kerja guru dalam mengelola proses pembelajaran, merupakan bagian integral dari serangkaian kegiatan supervisi akademik. Apabila dikatakan bahwa supervisi akademik merupakan serangkaian kegiatan membantu guru mengembangkan kemampuannya, maka dalam pelaksanaannya terlebih dahulu perlu diadakan penilaian kemampuan guru, sehingga bisa ditetapkan aspek yang perlu dikembangkan dan cara mengembangkannya. Jadi ibarat kita akan menembak dapat tepat pada sasaran.

Sergiovanni (1987) menegaskan bahwa refleksi praktis penilaian unjuk kerja guru dalam supervisi akademik adalah melihat realita kondisi untuk menjawab pertanyaan-pertanyaan, misalnya:

- Apa yang sebenarnya terjadi di dalam kelas?,

- Apa yang sebenarnya dilakukan oleh guru dan muridmurid di dalam kelas?,

- Aktivitas-aktivitas mana dari keseluruhan aktivitas di dalam kelas itu yang berarti bagi guru dan murid?,

- Apa yang telah dilakukan oleh guru dalam mencapai tujuan akademik?,

- Apa kelebihan dan kekurangan guru dan bagaimana cara mengembangkannya?

Berdasarkan jawaban terhadap pertanyaanpertanyaan ini akan diperoleh informasi mengenai kemampuan guru dalam mengelola kegiatan pembelajaran. Namun satu hal yang perlu ditegaskan di sini, bahwa setelah melakukan penilaian unjuk kerja guru tidak berarti selesailah tugas atau kegiatan supervisi akademik, melainkan harus dilanjutkan dengan perancangan dan pelaksanaan pengembangan.

Dengan demikian, melalui supervisi akademik guru akan semakin mampu memfasilitasi belajar bagi muridmuridnya.

2. Tujuan Supervisi akademik

Menurut sergiovanni (1987) ada tiga tujuan supervisi akademik, yaitu: a. Supervisi akademik diselenggarakan dengan maksud membantu guru mengembangkan kemampuannya profesionalnnya dalam memahami akademik, kehidupan kelas, mengembangkan keterampilan mengajarnya dan menggunakan kemampuannya melalui teknik-teknik tertentu.

b. Supervisi akademik diselenggarakan dengan maksud untuk memonitor kegiatan belajar mengajar di sekolah. Kegiatan memonitor ini bisa dilakukan melalui kunjungan kepala sekolah ke kelas-kelas di saat guru sedang mengajar, percakapan pribadi dengan guru, teman sejawatnya, maupun dengan sebagian muridmuridnya.

c. Supervisi akademik diselenggarakan untuk mendorong guru menerapkan kemampuannya dalam melaksanakan tugas-tugas mengajarnya, mendorong guru mengembangkan kemampuannya sendiri, serta mendorong guru agar ia memiliki perhatian yang sungguh-sungguh (commitment) terhadap tugas dan tanggung jawabnya.

Ada empat kompetensi guru yang harus dikembangkan melalui supervisi akademik, yaitu yaitu kompetensikompetensi kepribadian, pedagogik, professional, dan sosial. Aspek substansi pertama dan kedua merepresentasikan nilai, keyakinan, dan teori yang dipegang oleh guru tentang hakikat pengetahuan, bagaimana murid-murid belajar, penciptaan hubungan guru dan murid, dan faktor lainnya. Aspek ketiga berkaitan dengan seberapa luas pengetahuan guru tentang materi atau bahan pelajaran pada bidang studi yang diajarkannya.

Kedua, apa yang disebut dengan professional development competency Areas (yang selanjutnya akan disebut dengan aspek kompetensi). Aspek ini menunjuk pada luasnya setiap aspek substansi. Guru tidak berbeda dengan kasus profesional lainnya. la harus mengetahui bagaimana mengerjakan (know how to do) tugastugasnya. la harus memiliki pengetahuan tentang bagaimana merumuskan tujuan akademik, muridmuridnya, materi pelajaran, dan teknik akademik. Tetapi, mengetahui dan memahami keempat aspek substansi ini belumlah cukup. Seorang guru harus mampu menerapkan pengetahuan dan pemahamannya. Dengan kata lain, ia harus bisa mengerjakan (can do). Selanjutnya, seorang guru harus mau mengerjakan (will do) tugas-tugas berdasarkan kemampuan yang dimilikinya. Percumalah pengetahuan dan keterampilan yang dimiliki oleh seorang guru, apabila ia tidak mau mengerjakan tugas-tugasnya dengan sebaik-baiknya. Akhirnya seorang guru harus mau mengembangkan (will grow) kemampuan dirinya sendiri.

\section{Pengertian pendekatan supervisi kolaboratif}

Supervisi dapat diartikan melihat bagian mana dari kegiatan di sekolah yang masih negatif diupayakan untuk menjadi positif, dan yang sudah positif agar menjadi lebih positif lagi dengan adanya pembinaan. Sedangkan menurut Binti Maunah, Supervisi adalah suatu aktifitas pembinaan yang direncanakan untuk membantu para guru dan pegawai sekolah lainya dalam melakukan pekerjaan mereka secara efektif. 
Sedangkan pendekatan kolaboratif adalah cara pendekatan yang memadukan cara pendekatan direktif dan non-direktif menjadi pendekatan baru. Pada pendekatan ini baik supervisor maupun guru bersamasama, bersepakat untuk menetapkan struktur, proses dan kriteria dalam melaksanakan proses percakapan terhadap masalah yang dihadapi guru. Pendekatan ini ditempuh sebagai bentuk upaya dalam memahami orang yang disupervisi agar dalam melakukan supervisi dapat diperoleh hasil yang memuaskan sebagaimana yang diharapkan. Selain itu pendekatan ini juga mempunyai beberapa arti seperti misalnya, (I) Proses, perubahan, cara mendekati, (2) Usaha dalam rangka aktifitas penelitian untuk mengadakan hubungan dengan orang yang diteliti, atau metode-metode untuk mencapai pengertian tentang masalah penelitian seterusnya.

Dari pengertian yang pertama dapat dipahami bahwa pendekatan kolaboratif merupakan cara yang dipakai oleh seorang supervisor untuk mendekati orang yang disupervisi agar terjadi hubungan yang baik antara keduanya, sehingga dimungkinkan data yang diperoleh objektif serta mampu memberikan solusi bagi permasalahan yang muncul secara tepat.

4. Karakteristik pendekatan Kolaboratif

Sebagaimana telah diketahui bahwa supervisi adalah suatu teknik pelayanan yang tujuan utamanya mempelajari dan memperbaiki secara bersama-sama. Faktor - faktor yang mempengaruhi pertumbuhan dan perkembangan anak. Kegiatan ini diarahkan untuk membantu kinerja guru dalam melaksanakan tugasnya agar dapat mencapai target yang diinginkan.

Salah satu pendekatan dalam melaksanakan supevisi adalah pendekatan kolaboratif. Pendekatan ini memiliki karakteristik sebagai berikut:

a. Supervisor bertindak sebagai mitra atau rekan kerja.

- Kedua belah pihak berbagi kepakaran.

- Pendekatan yang digunakan merupakan pendekatan inkuiri yakni, saya mencoba memahami apa yang dilakukan oleh orang yang saya amati.

- Diskusi sebagai langkah lanjut dari pengalaman bersifat terbuka atau fleksibel dan tujuannya jelas.

- Tujuan supervisi ialah membantu guru dan berkembang menjadi tenaga-tenaga profesional.

- Dengan memahami karakteristik diatas dapat diilustrasikan bahwa dengan pendekatan kolaboratif, supervisi yang diterapkan akan terasa tenang dan tidak mengandung ketegangan.

b. Proses Pendekatan Supervisi Kolaboratif

jika diperhatikan secara seksama, pendekatan kolaboratif adalah perpaduan antara pendekatan Supervisi direktif dan non direktif. Dugaan itu benar, jika diperhatikan dari aspek tanggung jawab terlaksananya kegiatan Supervisi. Artinya supervisor dan guru berbagi tanggung jawab. Tugas Supervisi dalam hal ini adalah mendegarkan dan memperhatikan secara cermat keluhan guru terhadap masalah perbaikan, peningkatan dan pengembangan pengajarannya, dan sekaligus memperhatikan pula gagasan-gagasan guru untuk mengatasi masalah itu selanjutnya.
Beberapa pakar Supervisi mengemukakan, bahwa gagasan pendekatan kolaboratif dalam Supervisi, diilhami oleh gerakan hubungan instansi (The Human Relations Movement). Menurut Wiles \& Lovell, 1975 yang dikutip oleh sebuah blog, mengatakan bahwa gagasan ini sekaligus merupakan pula reaksi terhadap praktk model Supervisi klasik yang mengatakan bahwa fungsi Supervisi pengajaran adalah untuk mengawasi mutu dengan cara mengarahkan, menunjukkan, mengaharuskan, memantau menilai dan mengajar. Dalam praktek Supervisi, pendekatan ini disebut juga sebagai Supervisi kolegiat, kesejawatan atau korepatif, yang lebih banyak mengilhami karya para pakar Supervisi klinis.

Menurut glickman, gordon dan jovita, proses yang dilakukan dalam pendekatan cupervisi kolaboratif ini mencakup 10 langkah, yaitu clarifying, listening, reflecting, presenting, clarifying, problem solving, encouraging, negotiating, standardizing dan reflecting, yang akan dijelaskan dalam bahasan berikut ini.

Clarifying, mengidentifikasi masalah seperti yang terlihat oleh guru. Pertama, tanyakan guru tentang masalah langsung atau kekhawatiran: "tolong katakan padaku apa yang mengganggu Anda”. Jelaskan kepada saya apa yang anda lihat sebagai perhatian terbesar.

Listening, Mendengarkan: memahami persepsi guru. Anda (supervisor) ingin memiliki sebanyak mungkin informasi tentang masalah mungkin sebelum berpikir tentang tindakan. Oleh karena itu, ketika guru menceritakan persepsinya, berbagai perilaku non direktif harus digunakan (kontak mata, parafrase, mengajukan pertanyaan menyelidik, dan bersedia untuk memungkinkan guru untuk terus berbicara): "Ceritakan lebih banyak. Uh huh, aku mengikuti Anda. maksudmu?

Reflecting, Merefleksikan: memverifikasi persepsi guru. Ketika guru telah menyelesaikan deskripsi masalahnya, memeriksa akurasi dengan meringkas pernyataan guru dan menanyakan apakah ringkasannya Saya memahami bahwa Anda melihat masalah sebagai ...... apakah ini akurat?

Presenting, Menyajikan: menyediakan sudut pandang Sampai saat ini kita telah melihat konferensi non direktif disingkat. Alih-alih meminta guru untuk mulai memikirkan tindakan sendiri, namun Anda tahu bergerak dan menjadi bagian dari proses pengambilan keputusan. Berikan poin Anda sendiri pandang tentang kesulitan saat ini dan isi informasi tentang situasi dengan cara ini. Masalah seperti yang saya lihat adalah ... (untuk meminimalkan mempengaruhi posisi theacher itu, lebih baik bagi Anda untuk memberikan persepsi Anda hanya setelah guru telah memberikan nya atau miliknya.

Clarifying, Klarifikasi: mencari pemahaman guru tentang persepsi supervisor terhadap Dengan cara yang sama, Anda diparafrasekan pernyataan guru masalah dan meminta verifikasi, Anda sekarang meminta guru untuk melakukan hal yang sama: Anda bisa mengulangi apa yang Anda pikir saya sedang mencoba untuk mengatakan setelah Anda merasa yakin bahwa guru memahami pandangan Anda? pemecahan masalah dapat dimulai

Problem Solving, Pemecahan Masalah: Bertukar saran opsi. Jika Anda dan guru akrab satu sama lain dan 
telah bekerja bersama-sama sebelumnya, Anda hanya dapat meminta daftar saran: mari kita berdua berpikir tentang apa yang mungkin dilakukan untuk memperbaiki situasi ini. Kemudian mendengarkan ide masing-masing. Jika guru tidak akrab dengan Anda atau dengan proses kolaboratif, namun, ia mungkin merasa khawatir tentang menyarankan ide yang berbeda dari atasan. Mungkin lebih baik untuk menghentikan konferensi selama beberapa menit dan kedua pengawas dan guru menuliskan tindakan yang mungkin sebelum berbicara. Sehingga kita tidak saling mempengaruhi satu sama lain pada solusi yang mungkin, mari kita mengambil beberapa menit berikutnya dan menuliskan apa tindakan yang mungkin diambil dan kemudian membaca daftar masing-masing. Jelas, sekali tindakan yang secara tertulis, mereka tidak akan berubah sesuai dengan apa yang orang lain telah menulis. Anda pengawas, oleh karena itu, telah dipromosikan spektrum ide-ide pribadi yang siap untuk dibagikan dan didiskusikan.

Encouraging, menguatkan/ Mendorong: Menerima konflik. Untuk menjaga konferensi dari berubah menjadi perjuangan kompetitif, Anda perlu meyakinkan guru bahwa ketidaksepakatan diterima dan bahwa tidak akan ada pemenang atau pecundang. Tampaknya kita memiliki beberapa ide yang berbeda tentang bagaimana untuk menangani situasi ini. Dengan tidak setuju kita akan menemukan solusi terbaik sebelum akan berlangsung. Anda harus benar-benar percaya bahwa konflik antara dua profesional yang peduli sangat produktif untuk mencari solusi terbaik

Dan jika ada saran yang sangat berbeda. Di mana kita berbeda? Jika Anda menemukan kesepakatan, maka konferensi berlangsung. Tapi jika ada perbedaan besar dalam saran, maka Anda dapat mengambil tindakan untuk berurutan. Pertama cek untuk melihat apakah perbedaan yang luas muncul dengan memiliki diri sendiri dan guru menjelaskan secara menyeluruh apa yang dimaksud dengan saran Anda masing-masing. Kedua jika ketidaksepakatan masih nyata, kemudian mencari tahu seberapa yakin Anda masing-masing adalah bahwa saran Anda dipilih: bagaimana importants itu kepada Anda bahwa kami melakukannya dengan cara Anda? jika pentingnya saran satu orang jauh lebih besar dari saran orang lain, maka pertanyaannya menjadi apakah seseorang bisa menyerah atau ide nya dan hidup dengan lain. Ketiga, jika alasan untuk kesepakatan tidak tercapai, Anda dapat mempertimbangkan kompromi: bagaimana jika saya menyerah ini bagian dari saran saya dan jika Anda memberikan up..or melihat apakah ide yang sama sekali baru dapat ditemukan: karena kita tidak bisa setuju, mari kita turun Pilihan utama kami untuk solusi dan melihat apakah kita dapat menemukan satu sama lain. Keempat, jika masih belum ada gerakan dan jalan buntu yang benar tetap, maka Anda dapat panggilan untuk jangka waktu bagi kedua belah pihak untuk merenungkan masalah sebelum bertemu lagi.
Dengar, kita tidak mendapatkan di mana saja. Mari kita duduk di masalah ini dan bertemu lagi besok atau meminta orang ketiga untuk memainkan peran seorang mediator atau arbitrator. Kita tidak bisa setuju: bagaimana kalau kita menelepon seseorang bahwa kami berdua hormat untuk membantu kami mengatasi hal ini? Karena kita tidak bisa setuju, bagaimana menelepon seseorang kami berdua memiliki keyakinan dalam menyelesaikan ini bagi kita? Seorang mediator atau arbitrator adalah pilihan ekstrem bagi kebanyakan konferensi antara pengawas dan guru dan harus tetap menjadi pilihan terakhir. Namun, guru harus tahu bahwa prosedur kolaborasi memastikan bahwa dia tidak harus pergi bersama dengan rencana yang ia tidak setuju dengan. Ada pilihan lain yang tersedia.

\section{A. Pendekatan Penelitian}

\section{METODE PENELITIAN}

Penelitian ini merupakan penelitian tindakan sekolah (School Action Research), karena penelitian dilakukan untuk memecahkan masalah proses pembelajaran di sekolah. Penelitian ini menggambarkan bagaimana suatu teknik pembelajaran diterapkan dan bagaimana hasil yang diinginkan dapat dicapai. Penelitian ini mengambil bentuk penelitian tindakan sekolah (PTS) yaitu peningkatan kinerja guru melalui kunjungan kelas dalam rangka mengimplementasikan standar proses, yang terdiri dari 2 siklus dan masingmasing siklus terdiri dari 4 tahap yaitu :

(I) tahap perencanaan program tindakan,

(2) pelaksanaan program tindakan,

(3) pengamatan program,

(4) refleksi. Untuk lebih jelas lihat di bawah ini :

a) Rancangan /rencana awal, sebelum mengadakan penelitian peneliti menyusun rumusan masalah, tujuan dan membuat rencana tindakan, termasuk di dalamnya instrumen penelitian dan perangkat pembelajaran.

b) Tindakan dilakukan setelah rancangan disusun. Tindakan merupakan bagian yang akan dilakukan dalam Penelitian Tindakan Sekolah dalam penelitian.

c) Pengamatan dilakukan waktu guru mengajar di kelas. Data yang dikumpulkan dapat berupa data pengelolaan sekolah/madrasah. Instrumen yang umum dipakai adalah lembar observasi,dan cacatan lapangan yang dipakai untuk memperoleh data secara objektif yang tidak dapat terekam melalui lembar observasi, misalnya aktivitas siswa selama pemberian tindakan berlangsung, reaksi mereka, atau pentunjuk-petunjuk lain yang dapat dipakai sebagai bahan dalam analisis dan untuk keperluan refleksi.

d) Refleksi, peneliti mengkaji melihat dan mempertimbangkan hasil atau dampak dari tindakan yang dilakukan berdasarkan lembar pengamatan yang diisi oleh pengamat. 


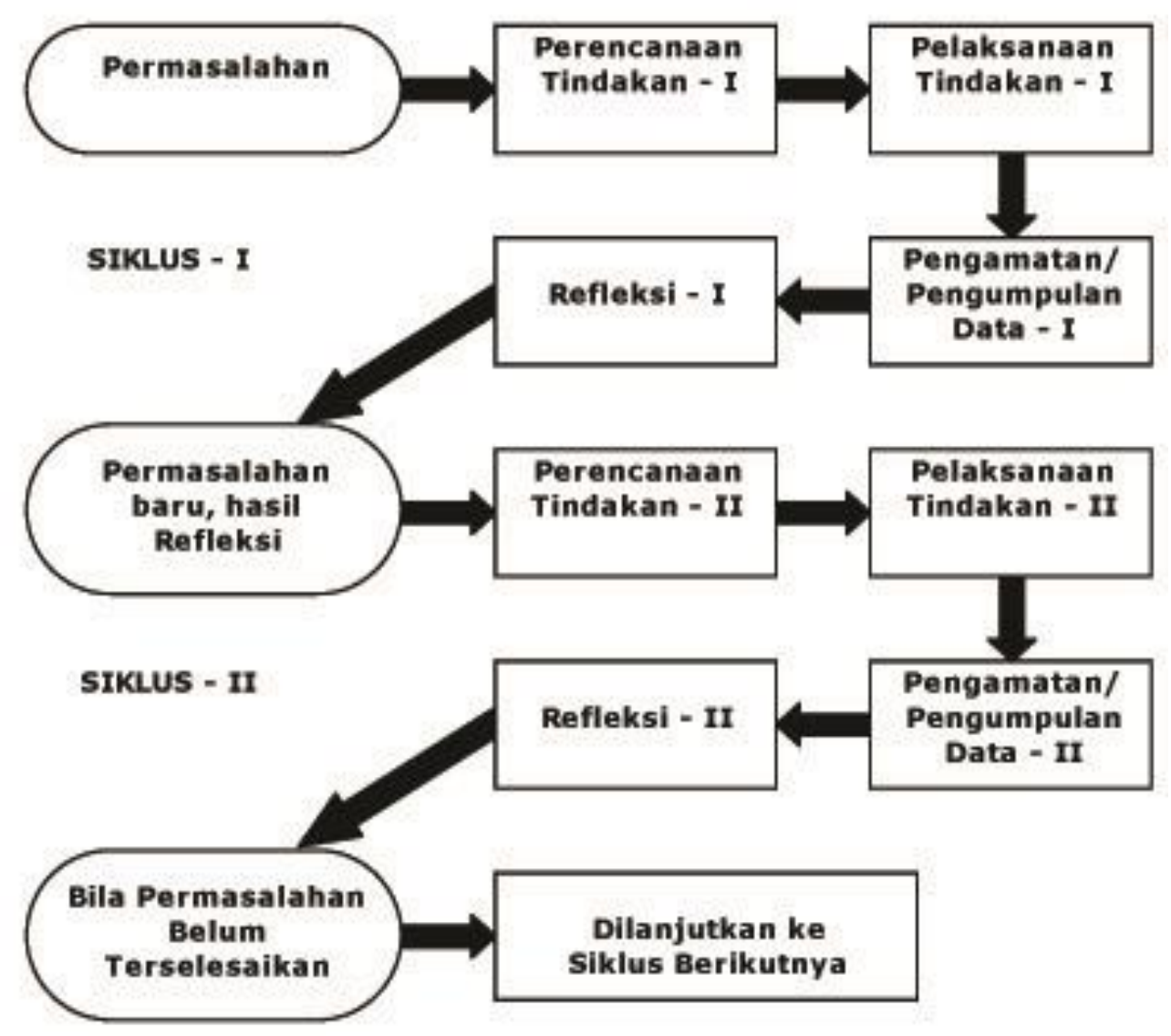

Gambar 2 Siklus Penelitian Tindakan Sekolah

\section{Siklus 2}

\section{a. Perencanaan}

Pada tahap ini peneliti merumuskan dan mempersiapkan melakukan tindak lanjut siklus I, yaitu dalam siklus II dilakukan perbaikan. Peneliti yang dalam hal ini adalah kepala sekolah mencari kekurangan dan kelebihan Supervisi akademik. Kelebihan yang ada pada siklus I dipertahankan pada siklus II, sedangkan kekurangannya diperbaiki. Peneliti menyiapkan lembar evaluasi (penilaian), lembar observasi untuk mengetahui peningkatan mutu kinerja guru .

\section{b. Tahap Pelaksanaan}

Pelaksanaan Siklus II juga dilaksanakan 2 kali selama seminggu. Proses tindakan pada siklus II dengan melaksanakan Supervisi akademik berdasarkan pada pengalaman hasil dari siklus I. Dalam tahap ini peneliti melaksanakan metode yang diterapkan berdasarkan Tindakan pada siklus I, perbedaannya adalah pada siklus II dilaksanakan dengan pemberian materi pada Supervisi akademik yang lebih detail lagi.

\section{c. Pengamatan}

Setelah proses bembinaan kedisiplinan selesai maka dilakukan pengamatan selama seminggu terhadap guru. Pengamatan dilakukan untuk mengetahui peningkatan mutu kinerja guru. Adapun yang di amati pada siklus II sama dengan yang diamati pada siklus I.

\section{d. Refleksi}

Refleksi merupakan kegiatan menganalisis semua data atau informasi yang dikumpulkan dari penelitian tindakan yang dilaksanakan, sehingga dapat diketahui berhasil atau tidaknya tindakan yang telah dilaksanakan dengan tujuan yang diharapkan.

\section{B. Teknik Pengumpulan Data}

Pengumpulan data dalam penelitian ini menggunakan tiga teknik yaitu :

I. Wawancara

Wawancara merupakan merupakan sebuah percakapan langsung antara si peneliti dengan responden yang diteliti yang dilakukan dengan tujuan untuk memperoleh informasi yang dibutuhkan. Dalam penelitian inti peneliti menggunakan pedoman wawancara yang sifatnya terbuka yang dimaksudkan agar peneliti tidak keluar dari apa yang sedang diteliti.

Untuk lebih memantapkan hasil wawancara peneliti melakukan cross check dengan melakukan wawancara selain dengan kepala sekolah juga dengan guru.

2. Observasi

Observasi adalah pengamatan dan pencatatan yang sistematis terhadap gejala- gejala yan diteliti (Husaini Usman dan Purnomo Setiady Akbar, 200I: 54). Dari pengertian tersebut sudah jelas bahwa observasi merupakan pengamatan langsung terhadap suatu kegiatan yang sedang dilakukan. Sehingga, dalam penelitian ini peneliti melakukan pengamatan secara 
langsung terhadap mutu kinerja guru. Teknik ini digunakan untuk mendapatkan data yang cermat dan faktual.

Obsevasi ini dilakukan secara berkelanjutan dengan memperhatikan situasi dan kondisi yang terjadi di sekolah tersebut, sehingga akan diperoleh informasi yang sesuai dengan kebutuhan peneliti.

3. Studi dokumentasi

Penelitian kualitatif selain menggunakan observasi dan wawancara dalam mencari sumber data, tetapi masih perlu dilakukan dengan studi dokumentasi yang dilakukan dengan melihat, mengamati dan menganalisis dokumen-dokumen agar mampu menguatkan hasil yang diperoleh dengan melakukan obsevasi dan wawancara. Peneliti melakukan studi dokumentasi untuk dimanfaatkan sebagai bahan triangulasi untuk pengecekan kesesuaian data.

\section{Instrumen Penelitian}

Menurut Nurul Zuriah (2007: 168) dikatakan bahwa instrumen penelitian merupakan alat bantu bagi peneliti dalam mengumpulkan data. Dalam melakukan penelitian, seorang peneliti harus mampu membuat instrumen sendiri termasuk mengkaji indikator sejelasjelasnya sehingga bisa diukur dan menghasilkan data yang diinginkan. Instruman yang digunakan peneliti dalam melakukan penelitian kualitatif adalah si peneliti itu sendiri sebab dibutuhkan pengamatan langsung oleh peneliti untuk melihat objek di lapangan. Sehingga, peneliti bisa melakukan pengamatan secara mendalam.

Dalam penelitian ini peneliti menggunakan instrumen penelitian dengan wawancara, observasi dan studi dokumentasi.

\section{Teknik Analisis Data}

Analisis data dalam penelitian kualitatif dilakukan pada saat pengumpulan data berlangsung dan setelah selesai pengumpulan data dalam periode tertentu. Menurut Sugiyono (2009:246) kegiatan yang dilakukan yaitu data reduction, data display dan conclusion drawing/ verification.

Data yang telah diperoleh dari lapangan, kemudian diolah agar lebih sederhana. Kegiatan analisis data yang dilakukan yaitu :

I. Reduksi data

Mereduksi berarti merangkum, memilih hal-hal yang pokok, memfokuskan pada hal-hal yang penting, dicari tema dan polanya (Sugiyono, 2009:247). Mereduksi data akan mempermudah dan akan memperjelas dalam memberikan gambaran yang telah diperoleh di lapangan serta dapat mempermudah peneliti ketika melakukan pengumpulan data berikutnya. Selain itu, peneliti dapat memilah-milah mana yang relevan atau sesuai dengan fokus penelitian, sehingga akan dapat menjawab pertanyaan peneliti.

\section{Penyajian data}

Langkah selanjutnya setelah reduksi data yaitu mendisplay-kan data atau penyajian data yang dimaksudkan agar mudah dipahami apa yang terjadi sebenarnya di lapangan, dapat merencanakan kerja selanjutnya berdasarkan apa yang telah dipahami (Sugiyono, 2009:249).

3. Penarikan kesimpulan

Langkah yang selanjutnya yaitu peneliti melakukan penarikan kesimpulan. Kesimpulan awal yang dikemukakan masih bersifat sementara, dan dapat berubah bila tidak ditemukan bukti-bukti yang kuat yang mendukung pada tahap pengumpulan data berikutnya. Kesimpulan dalam penelitian kualitatif akan dapat menjawab rumusan masalah yang dirumuskan sejak awal, tetapi mungkin juga tidak sebab rumusan masalah dalam penelitian kualitatif masih bersifat sementara dan akan berkembang setelah penelitian di lapangan. Kesimpulan dalam penelitian kualitatif merupakan temuan baru yang belum pernah ada. Temuan dapat berupa deskripsi atau gambaran suatu objek yang sebelumnya masih remang-remang, sehingga setelah diteliti menjadi jelas (Sugiyono, 2009:253).

\section{E. Indikator Kinerja}

Tujuan penelitian tindakan sekolah yang di lakukan pada guru di SDN 2 Pasir Panjang adalah dalam meningkatkan mutu kinerja guru melalui Supervisi akademik. Maka yang menjadi indikator kinerja dalam penelitian ini adalah Supervisi akademik dapat menjadi pendekatan yang efektif kepada guru dalam meningkatkan mutu kinerja guru. Untuk mengukur keberhasilan penelitian ini adalah penelitian ini dapat menjawab:

I. Bagaimana pelaksanaan supervisi akademik di SDN 2 Pasir Panjang tahun 2019.

2. Sejauh mana supervisi akademik dalam meningkatkan mutu kinerja guru di SDN 2 Pasir Panjang tahun 2019.

\section{HASIL PENELITIAN DAN PEMBAHASAN}

\section{A. Hasil Penelitian}

\section{Hasil Penelitian Pra Tindakan}

Penelitian ini dilaksanakan di SDN 2 Pasir Panjang dengan subjek penelitian adalah guru yang ada di sekolah ini, baik yang sudah pegawai negeri sipil maupun yang masih wiyata bakti. Adapun mutu kinerja guru yang ada di SDN 2 Pasir Panjang adalah sebagai berikut:

$\begin{array}{ccrr}\text { Berikut } & \text { adalah hasil } & \text { supervisi } & \text { pra } \\ \text { tentang } & \text { mutu } & \text { kinerja } & \text { guru }\end{array}$


Tabel 3

FORMAT INSTRUMEN PENILAIAN MUTU KINERJA GURU

Penilai : SUPRIYANTO, S.Pd SD

\begin{tabular}{|c|c|c|c|c|c|c|}
\hline \multirow[t]{2}{*}{ No } & \multirow[t]{2}{*}{ URAIAN KEGIATAN } & \multicolumn{4}{|c|}{ Hasil Telaah } & \multirow[t]{2}{*}{ Ket } \\
\hline & & $\mathbf{I}$ & 2 & 3 & 4 & \\
\hline I & Persiapan & & & & & \\
\hline & a. Guru membuka pembelajaran tepat waktu & & & & & \\
\hline & b. Mengabsen siswa & & & & & \\
\hline & c. Memotivasi siswa & & & & & \\
\hline & d. Mengapresiasi siswa & & & & & \\
\hline 2 & Apersepsi & & & & & \\
\hline & $\begin{array}{l}\text { a. Menjelaskan Kompetensi Dasar dan } \\
\text { Tujuan Pembelajaran }\end{array}$ & & & & & \\
\hline & $\begin{array}{l}\text { b. Menyampaikan Cakupan Materi dan Keterkaitan Dengan Materi } \\
\text { Sebelumnya }\end{array}$ & & & & & \\
\hline & $\begin{array}{l}\text { c. Menyampaikan Uraian/ Langkah } \\
\text { Kegiatan Sesuai dengan Silabus }\end{array}$ & & & & & \\
\hline & $\begin{array}{l}\text { d. Menyampaikan cakupan Materi Kaitan } \\
\text { dengan Kondisi Nyata/ Riil Saat Ini }\end{array}$ & & & & & \\
\hline 3 & $\begin{array}{l}\text { Relevansi Materi dengan Tujuan } \\
\text { Pembelajaran }\end{array}$ & & & & & \\
\hline & $\begin{array}{l}\text { a. Materi Sesuai dengan Tujuan } \\
\text { Pembelajaran }\end{array}$ & & & & & \\
\hline & $\begin{array}{l}\text { b. Materi Diperkaya dengan } \\
\text { Perkembangan Terkini yang Relevan }\end{array}$ & & & & & \\
\hline & $\begin{array}{l}\text { c. Tersedianya Peta Konseptual (Mind } \\
\text { Mapping) Tujuan Pembelajaran dan Materi Ajar atau Sejenisnya }\end{array}$ & & & & & \\
\hline 4 & Penugasan Materi & & & & & \\
\hline & a. Tidak Terpaku pada Buku Teks & & & & & \\
\hline & $\begin{array}{l}\text { b. Mampu Menjawab Pertanyaan dan/ } \\
\text { atau Menyelesaikan Soal Tanpa Keraguan }\end{array}$ & & & & & \\
\hline & $\begin{array}{l}\text { c. Tidak Diam Sejenak atau Bahkan Lupa } \\
\text { Ketika Mengajarkan Materi }\end{array}$ & & & & & \\
\hline
\end{tabular}


Supriyanto. Peningkatan Mutu Kinerja Guru Melalui Supervisi Akademik Di SDN 2 Pasir Panjang Semester I Tahun Pelajaran 2019/2020

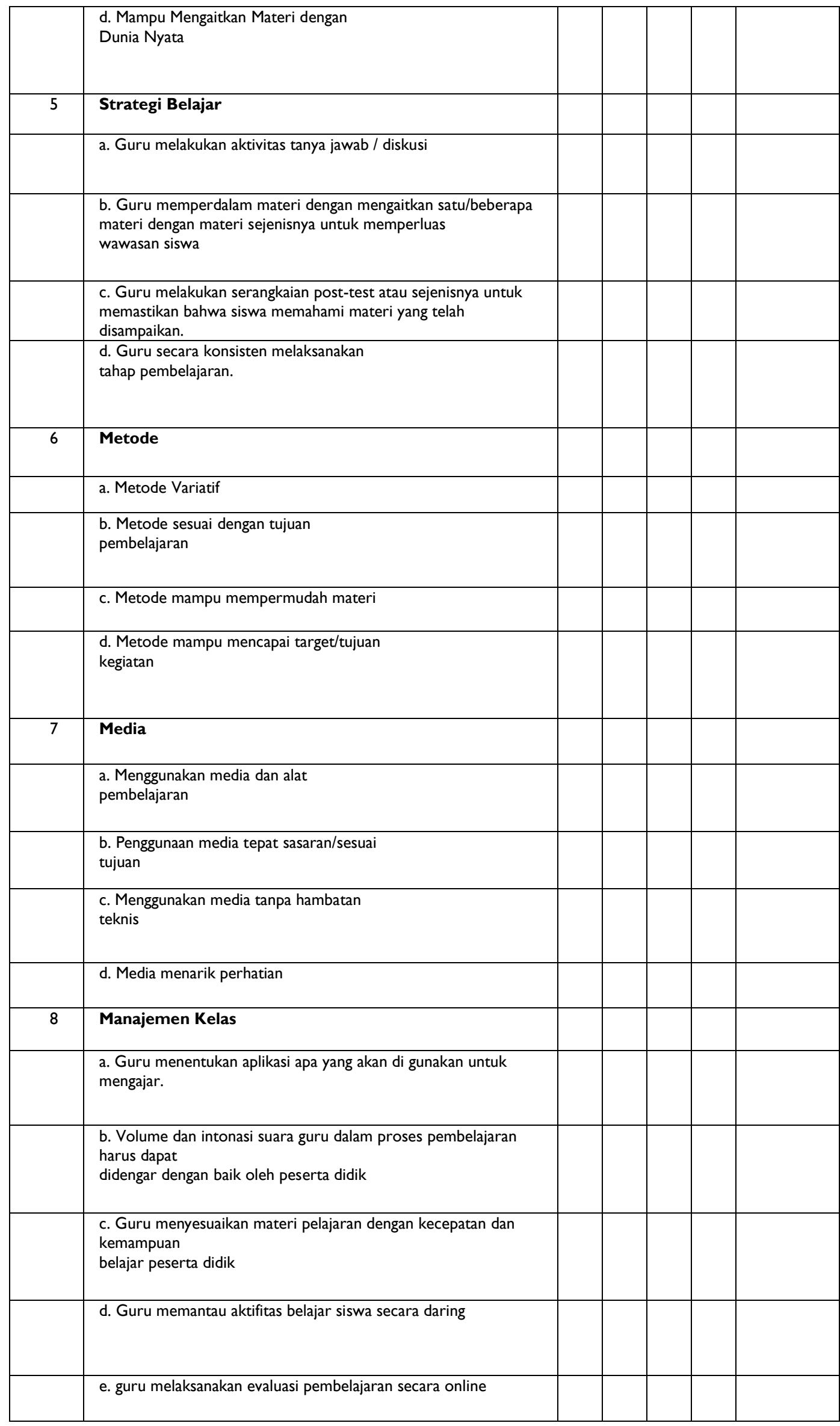




\begin{tabular}{|c|c|c|c|}
\hline & $\begin{array}{l}\text { f. guru menghargai peserta didik tanpa memandang latar belakang } \\
\text { agama, suku, } \\
\text { jenis kelamin, dan status sosial ekonomi }\end{array}$ & & \\
\hline & g. guru menghargai pendapat peserta didik & & \\
\hline & h. guru menguasai aplikasi pembelajaran & & \\
\hline & i. Guru mengajar sesuai RPP dan silsbus yang telah di susun & & \\
\hline & $\begin{array}{l}\text { j. guru memulai dan mengakhiri proses } \\
\text { pembelajaran sesuai dengan waktu yang dijadwalkan }\end{array}$ & & \\
\hline 9 & Pemberian Motivasi Kepada Siswa & & \\
\hline & $\begin{array}{l}\text { a. Memberikan penguatan atau penghargaan (reward) kepada siswa } \\
\text { baik berupa kata-kata, sentuhan atau bentuk laiinya. }\end{array}$ & & \\
\hline & $\begin{array}{l}\text { b. Melaksanakan penilaian selama kegiatan } \\
\text { berlangsung }\end{array}$ & & \\
\hline & $\begin{array}{l}\text { c. Mampu memberikan motivasi dengan } \\
\text { tepat }\end{array}$ & & \\
\hline & $\begin{array}{l}\text { d. Respon terhadap keadaan motivasi belajar siswa dengan } \\
\text { melakukan aktivitas yang dapat meningkatkan motivasi }\end{array}$ & & \\
\hline 10 & Gaya dan Sikap Perilaku & & \\
\hline & a. Bertutur kata santun dan edukatif & & \\
\hline & $\begin{array}{l}\text { b. Empati kepada siswa yang tidak mempunyai HP atau quota } \\
\text { internet }\end{array}$ & & \\
\hline & c. Menggunakan bahasa tubuh secara tepat & & \\
\hline & $\begin{array}{l}\text { d. Menengur dan menyelesaikan dengan baik segala bentuk } \\
\text { gangguan dalam belajar. }\end{array}$ & & \\
\hline & Jumlah Nilai Real =............. & & \\
\hline & Jumlah Nilai Ideal $=10 \times 4=40$ & \multirow{2}{*}{\multicolumn{2}{|c|}{ Klasifikasi $=\ldots . . . . . . . . . . . .}}$. \\
\hline & Prosentase & & \\
\hline
\end{tabular}

Keterangan:

4 : Amat Baik (Skor 4)

3: Baik (Skor 3)

2: Cukup (Skor 2)

I: Kurang (Skor I)

Skor Maksimal: 4 X 45=180

Kriteria Penilaian

A: 120-180 : Mutu kinerja guru Tinggi

B:60-119: Mutu kinerja guru Sedang

C: $\leq 59$ : Mutu kinerja guru Rendah 
Berikut adalah hasil penilaian mutu kinerja guru pada pra siklus:

Tabel 4

Data Hasil Penilaian Mutu Kinerja Guru Pra Tindakan

\begin{tabular}{|c|l|c|l|}
\hline No & Nama Guru & Skor & Ket \\
\hline I & WDS & & \\
\hline 2 & TGM & 50 & Rendah \\
\hline 3 & AGS & 50 & Sedang \\
\hline 4 & KWA & 56 & Rendah \\
\hline 5 & NNS & 60 & Rendah \\
\hline 6 & HTS & 65 & Rendah \\
\hline 7 & KRT & 55 & Rendah \\
\hline 8 & RMH & 50 & Rendah \\
\hline 9 & RTM & 50 & Rendah \\
\hline I0 & DWS & 55 & Rendah \\
\hline \multicolumn{2}{|c|}{ Skor Rata-rata } & 57,5 & Rendah \\
\hline
\end{tabular}

\section{Diagram I Hasil Penilaian Mutu Kinerja Guru Pra Tindakan}
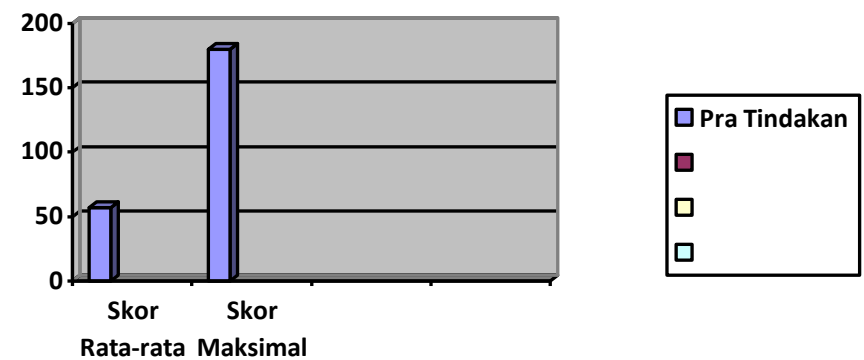

2.

\section{Pelaksanaan Siklus I}

\section{a. Tahap Perencanaan}

Pada perencanaan, peneliti melaksanakan program Supervisi akademik dalam meningkatkan mutu kinerja guru. berikut:

Pada tahap perencanaan peneliti menyiapkan hal

Rencana jadwal pelaksanaan tindakan,

$>$ Rencana pelaksanaan supervisi akademik,

$>$ Membuat lembar observasi, dan

$>$ Mempersiapkan kelengkapan lain yang diperlukan dalam rangka analisis data.

\section{b. Tahap Pelaksanaan}

Adapun pelaksanannya adalah sebagai berikut:

Berikut adalah hasil supervisi siklus I:
Peneliti melakukan apersepsi

> Peneliti melaksanakan supervisi akademik

$>$ Peneliti menyampaikan tujuan yang akan dicapai

$>$ Peneliti memantau kinerja guru dengan meminta laporan mutu kinerja guru

$>$ Guru praktek mengajar di kelas

$>$ Peneliti mendampingi guru mengisi lembar penilaian c. Pengamatan

Setelah kegiatan Supervisi akademik berlangsung, peneliti bertindak sebagai supervisor yang bertugas mengamati mutu kinerja guru dengan mengisi lembar penilaian yang telah disusun sebelum melaksanakan kegiatan penelitian. Hal ini dilakukan untuk mengetahui peningkatan mutu kinerja guru.

Tabel 5

Data Hasil Penilaian Mutu Kinerja Guru Siklus I

\begin{tabular}{|c|l|c|c|}
\hline No & Nama Guru & Skor & Ket \\
& & & \\
\hline I & WDS & 70 & Sedang \\
\hline 2 & TGM & 120 & Tinggi \\
\hline 3 & AGS & 85 & Sedang \\
\hline 4 & KWA & 86 & Sedang \\
\hline
\end{tabular}




\begin{tabular}{|c|l|c|c|}
\hline 5 & NNS & 80 & Sedang \\
\hline 6 & HTS & 85 & Sedang \\
\hline 7 & KRT & 85 & Sedang \\
\hline 8 & RMH & 90 & Sedang \\
\hline 9 & RTM & 90 & Sedang \\
\hline I0 & DWS & 85 & Sedang \\
\hline \multicolumn{2}{|l}{ Skor Rata-rata } & 93,9 & Rendah \\
\hline
\end{tabular}

Kriteria Penilaian

A: 120-180: Mutu kinerja guru Tinggi

B:60-I 19: Mutu kinerja guru Sedang

C: $\leq 59$ : Mutu kinerja guru Rendah

\section{Diagram 2 Hasil Penilaian Mutu kinerja guru Siklus I}

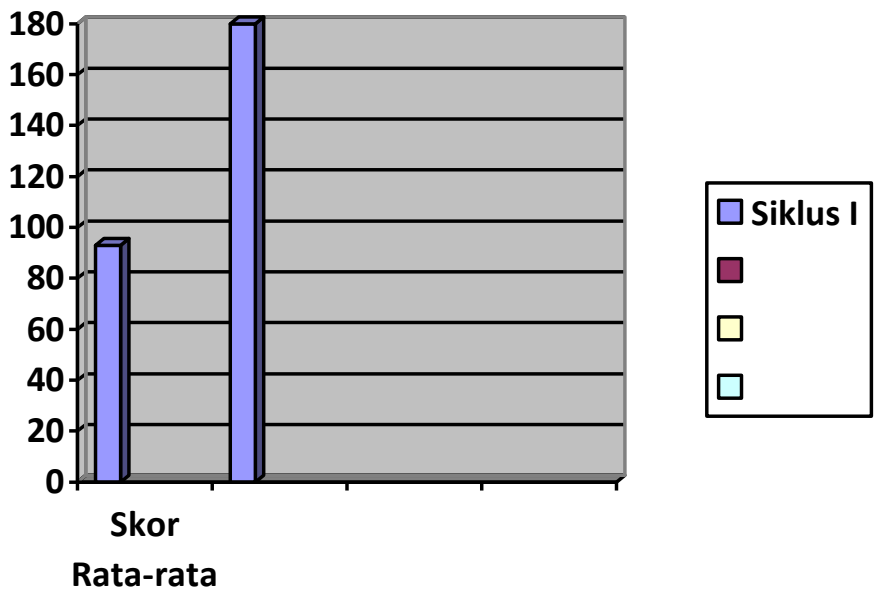

C

\section{. Refleksi}

Data penelitian tindakan sekolah yang diperoleh dari Hasil penilaian mutu kinerja guru pada siklus I, hasilnya adalah mutu kinerja guru sedang. Hal ini di tunjukkan dengan adanya perolehan skor rata-rata hasil penilaian siklus I yaitu 93,9, akan tetapi perlu peningkatan ke skor yang lebih tinggi lagi agar mencapai skor maksimal.

Dengan adanya hasil observasi dan penilaian pada kegiatan siklus I maka peneliti melakukan refleksi. Dari refleksi terhadap seluruh kegiatan pada siklus I, maka refleksi pada siklus I adalah sebagai berikut:

I. Guru sudah mampu melaksanakan persiapan pembelajaran secara optimal

2. Guru sudah mampu melaksanakan Apersepsi pembelajaran secara optimal

3. Relevansi materi dengan tujuan pembelajaran sudah sesuai

4. Guru sudah mampu memberikan penugasan materi

5. Strategi pembelajaran yang di gunakan guru sudah baik

6. Metode pembelajaran yang di gunakan guru sudah baik

7. Media pembelajaran yang di gunakan guru sudah baik

8. Manajemen kelas sudah mulai optimal

9. Guru memberikan motivasi siswa dengan baik

\section{Pelaksanaan Siklus II}

Berikut adalah hasil supervisi siklus II:

\section{a. Tahap Perencanaan}

Pada perencanaan, peneliti melaksanakan program Supervisi akademik dalam meningkatkan mutu kinerja guru. berikut:

Pada tahap perencanaan peneliti menyiapkan hal

Rencana jadwal pelaksanaan tindakan,

Rencana pelaksanaan supervisi akademik,

$>$ Membuat lembar observasi, dan

$>$ Mempersiapkan kelengkapan lain yang diperlukan dalam rangka analisis data.

\section{b. Tahap Pelaksanaan}

Adapun pelaksanannya adalah sebagai berikut:

Peneliti melakukan apersepsi

> Peneliti melaksanakan supervisi akademik

> Peneliti menyampaikan tujuan yang akan dicapai

$>$ Peneliti memantau kinerja guru dengan meminta laporan mutu kinerja guru

$>$ Guru praktek mengajar di kelas

$>$ Peneliti mendampingi guru mengisi lembar penilaian

\section{c. Pengamatan}

Setelah kegiatan Supervisi akademik berlangsung, peneliti bertindak sebagai supervisor yang bertugas mengamati mutu kinerja guru dengan mengisi lembar penilaian yang telah disusun sebelum melaksanakan kegiatan penelitian. Hal ini dilakukan untuk mengetahui peningkatan mutu kinerja guru. 
Tabel 6

Data Hasil Penilaian Mutu Kinerja Guru Siklus II

\begin{tabular}{|c|l|r|c|}
\hline No & Nama Guru & Skor & Ket \\
\hline 1 & WDS & 130 & Tinggi \\
\hline 2 & TGM & 160 & Tinggi \\
\hline 3 & AGS & 135 & Tinggi \\
\hline 4 & KWA & 136 & Tinggi \\
\hline 5 & NNS & 120 & Tinggi \\
\hline 6 & HTS & 125 & Tinggi \\
\hline 7 & KRT & 125 & Tinggi \\
\hline 8 & RMH & 130 & Tinggi \\
\hline 9 & RTM & 130 & Tinggi \\
\hline I0 & DWS & 135 & Tinggi \\
\hline Skor Rata-rata & 135,79 & Tinggi \\
\hline
\end{tabular}

Kriteria Penilaian

A: 120-180: Mutu kinerja guru Tinggi

B:60-1 19: Mutu kinerja guru Sedang

C: $\leq 59$ : Mutu kinerja guru Rendah

Hasil penelitian siklus II dapat di baca melalui diagram berikut:

\section{Diagram 3 Hasil Penilaian Mutu Kinerja Guru Siklus II}

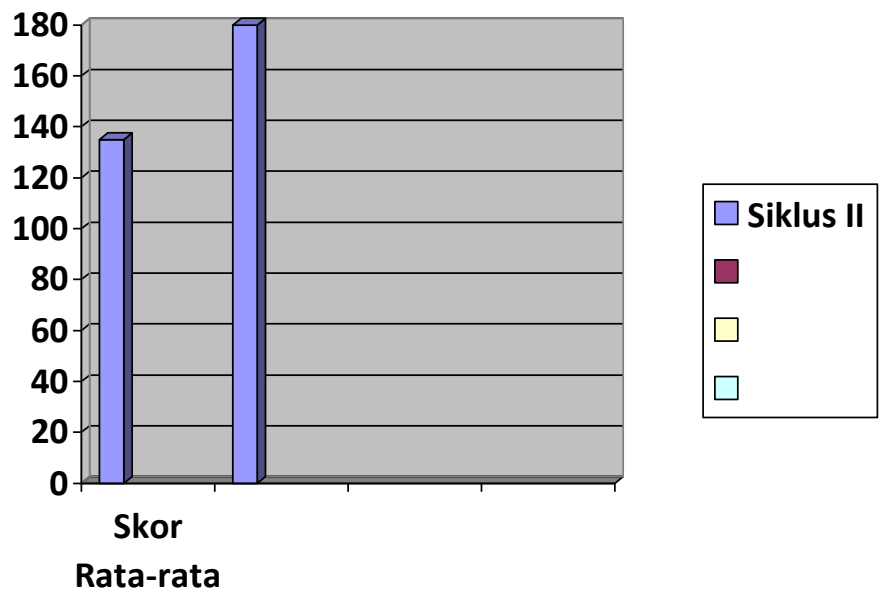

\section{c. Refleksi}

Data penelitian tindakan sekolah yang diperoleh dari Hasil penilaian mutu kinerja guru pada siklus II, hasilnya adalah mutu kinerja guru tinggi. Hal ini di tunjukkan dengan adanya perolehan skor rata-rata hasil penilaian siklus II yaitu 135,79, hal ini sudah memenuhi target karena mencapai skor maksimal yaitu mendekati 180.

Dengan adanya hasil observasi dan penilaian pada kegiatan siklus II maka peneliti melakukan refleksi. Dari refleksi terhadap seluruh kegiatan pada siklus II, maka refleksi pada siklus II adalah sebagai berikut:

I. Guru sudah mampu melaksanakan persiapan pembelajaran secara optimal
2. Guru sudah mampu melaksanakan Apersepsi pembelajaran secara optimal

3. Relevansi materi dengan tujuan pembelajaran sudah sesuai

4. Guru sudah mampu memberikan penugasan materi

5. Strategi pembelajaran yang di gunakan guru sudah baik

6. Metode pembelajaran yang di gunakan guru sudah baik

7. Media pembelajaran yang di gunakan guru sudah baik

8. Manajemen kelas sudah mulai optimal

9. Guru memberikan motivasi siswa dengan baik

\section{B. Pembahasan}

Berdasarkan observasi pendahuluan dan wawancara langsung dengan kepala guru-guru SDN 2 Pasir Panjang memiliki kinerja yang kurang baik. guruguru SDN 2 Pasir Panjang belum memiliki kedisiplinan 
yang tinggi yang ditujukan kepada seluruh warga sekolah. Dengan fasilitas yang kurang memadai SDN 2 Pasir Panjang jadi kurang mampu bersaing dengan sekolah lain. Oleh karenanya peneliti hendak meningkatkan mutu kinerja guru SDN 2 Pasir Panjang melalui supervisi akademik. Penelitian ini merupakan penelitian tindakan sekolah (School Action Research).Penelitian ini akan dilaksanakan di SDN 2 Pasir Panjang.Penelitian akan dilakukan pada semester ganjil tahun 2019.subjek penelitian adalah guru yang ada di sekolah ini, baik yang sudah pegawai negeri sipil maupun yang masih wiyata bakti. Pengumpulan data dalam penelitian ini menggunakan tiga teknik yaitu wawncara, observasi dan dokumentasi.

Data penelitian tindakan sekolah yang diperoleh dari Hasil penilaian mutu kinerja guru pada pra siklus, hasilnya adalah mutu kinerja guru rendah. Hal ini di tunjukkan dengan adanya perolehan skor rata-rata hasil penilaian siklus I yaitu 57,5, oleh karenanya perlu peningkatan ke skor yang lebih tinggi lagi agar mencapai skor maksimal.

Hasil penilaian mutu kinerja guru pada siklus I, hasilnya adalah mutu kinerja guru sedang. Hal ini di tunjukkan dengan adanya perolehan skor rata-rata hasil penilaian siklus I yaitu 93,9 , akan tetapi perlu peningkatan ke skor yang lebih tinggi lagi agar mencapai skor maksimal.

Dengan adanya hasil observasi dan penilaian pada kegiatan siklus I maka peneliti melakukan refleksi. Dari refleksi terhadap seluruh kegiatan pada siklus I, maka refleksi pada siklus I adalah sebagai berikut:

Data penelitian tindakan sekolah yang diperoleh dari Hasil penilaian mutu kinerja guru pada siklus II, hasilnya adalah mutu kinerja guru tinggi. Hal ini di tunjukkan dengan adanya perolehan skor rata-rata hasil penilaian siklus II yaitu 135,79, hal ini sudah memenuhi target karena mencapai skor maksimal yaitu mendekati 180 .

Dengan adanya hasil observasi dan penilaian pada kegiatan siklus II maka peneliti melakukan refleksi. Dari refleksi terhadap seluruh kegiatan pada siklus II, maka refleksi pada siklus II adalah sebagai berikut:

I. Guru sudah mampu melaksanakan persiapan pembelajaran secara optimal

2. Guru sudah mampu melaksanakan Apersepsi pembelajaran secara optimal

3. Relevansi materi dengan tujuan pembelajaran sudah sesuai

4. Guru sudah mampu memberikan penugasan materi

5. Strategi pembelajaran yang di gunakan guru sudah baik

6. Metode pembelajaran yang di gunakan guru sudah baik

7. Media pembelajaran yang di gunakan guru sudah baik

8. Manajemen kelas sudah mulai optimal

9. Guru memberikan motivasi siswa dengan baik

\section{KESIMPULAN DAN SARAN}

\section{A. Kesimpulan}

Berdasarkan observasi pendahuluan dan wawancara langsung dengan kepala guru-guru SDN 2 Pasir Panjang memiliki kinerja yang kurang baik. guru- guru SDN 2 Pasir Panjang belum memiliki kedisiplinan yang tinggi yang ditujukan kepada seluruh warga sekolah. Dengan fasilitas yang kurang memadai SDN 2 Pasir Panjang jadi kurang mampu bersaing dengan sekolah lain. Oleh karenanya peneliti hendak meningkatkan mutu kinerja guru SDN 2 Pasir Panjang melalui supervisi akademik. Penelitian ini merupakan penelitian tindakan sekolah (School Action Research).Penelitian ini akan dilaksanakan di SDN 2 Pasir Panjang.Penelitian akan dilakukan pada semester ganjil tahun 2019. Subjek penelitian adalah guru yang ada di sekolah ini, baik yang sudah pegawai negeri sipil maupun yang masih wiyata bakti. Pengumpulan data dalam penelitian ini menggunakan tiga teknik yaitu wawncara, observasi dan dokumentasi.

Data penelitian tindakan sekolah yang diperoleh dari Hasil penilaian mutu kinerja guru pada pra siklus, hasilnya adalah mutu kinerja guru rendah. Hal ini di tunjukkan dengan adanya perolehan skor rata-rata hasil penilaian siklus I yaitu 57,5, oleh karenanya perlu peningkatan ke skor yang lebih tinggi lagi agar mencapai skor maksimal.

Hasil penilaian mutu kinerja guru pada siklus I, hasilnya adalah mutu kinerja guru sedang. Hal ini di tunjukkan dengan adanya perolehan skor rata-rata hasil penilaian siklus I yaitu 93,9 , akan tetapi perlu peningkatan ke skor yang lebih tinggi lagi agar mencapai skor maksimal.

Dengan adanya hasil observasi dan penilaian pada kegiatan siklus I maka peneliti melakukan refleksi. Dari refleksi terhadap seluruh kegiatan pada siklus I, maka refleksi pada siklus I adalah sebagai berikut:

Data penelitian tindakan sekolah yang diperoleh dari Hasil penilaian mutu kinerja guru pada siklus II, hasilnya adalah mutu kinerja guru tinggi. Hal ini di tunjukkan dengan adanya perolehan skor rata-rata hasil penilaian siklus II yaitu 135,79, hal ini sudah memenuhi target karena mencapai skor maksimal yaitu mendekati 180.

Dengan adanya hasil observasi dan penilaian pada kegiatan siklus II maka peneliti melakukan refleksi. Dari refleksi terhadap seluruh kegiatan pada siklus II, maka refleksi pada siklus II adalah sebagai berikut:

I. Guru sudah mampu melaksanakan persiapan pembelajaran secara optimal

2. Guru sudah mampu melaksanakan Apersepsi pembelajaran secara optimal

3. Relevansi materi dengan tujuan pembelajaran sudah sesuai

4. Guru sudah mampu memberikan penugasan materi

5. Strategi pembelajaran yang di gunakan guru sudah baik

6. Metode pembelajaran yang di gunakan guru sudah baik

7. Media pembelajaran yang di gunakan guru sudah baik

8. Manajemen kelas sudah mulai optimal

9. Guru memberikan motivasi siswa dengan baik

\section{B. Saran}

Peneliti membuat saran-saran berikut:

I. Untuk Guru 
Dengan meningkatkan mutu kinerja guru sudah tentu akan membawa dampak positif baik bagi diri guru sendiri dan juga bagi para siswa.

2. Untuk Para kepala sekolah

Bagi para Kepala sekolah teruslah mencari dan menerapkan program-program yang pas dan cocok untuk memperbaiki kualitas pengajar di sekolah. Hal ini akan menunjang sekali pada tercapainya tujuan pembelajaran.

3. Bagi kalangan umum

Bagi kalangan umum bisa membaca dan menjadikan refrensi hasil tulisan saya ini untuk memilih metode dalam meningkatkan Mutu kinerja guru.

\section{DAFTAR PUSTAKA}

A.A. Anwar Prabu Mangkunegara. (200I), Manajemen sumber daya manusia perusahaan, Bandung : Remaja Rosdakarya.

Anwar Prabu Mangkunegara. (200 I), Manajemen sumber daya manusia perusahaan, Bandung : Remaja Rosdakarya.

Arikunto, Manajemen Pendidikan, Yogyakarta: Aditya Media, 2009

Arikunto, Suharsimi, 2004, Dasar-dasar Supervisi, Jakarta, PT. Rineka Cipta.

Arikunto, Suharsimi. 2004. Dasar-dasar Supervisi, Jakarta: Rineka Cipta

Buku Materi Bafadal, I. 2006. Peningkatan Profesionalisme Guru Sekolah Dasar. Jakarta: Bumi Aksara.

Daresh. (1989). Supervison as Approactive Process. New Jersey: Longman.

Departemen Pendidikan dan Kebudayaan, 1995. Pedoman Pembinaan Profesional Sekolah Dasar. Dikdasmen: Jakarta
Departemen Pendidikan Nasional, 2008. Petunjuk TeknisPenelitian Tindakan Sekolah. Dirjen PMTK: Jakarta.

Depdiknas. 2005. Kamus Besar Bahasa Indonesia Edisi Ke 3. Jakarta: Balai Pustaka.

Glickman, Carl.AD, (198I) Development Supervision (alternative Practice for Helping Teacher Improve Intruktion) Virginia ASCD

Glickman, Stephen, Jovita. 2009. The Basic Guide to Supervision and Instructional Leadership, USA: Pearson

H.A.R. Tilaar.(2004).MULTIKULTURALISME Tantangantantangan Global Masa Depan dalam Transformasi Pendidikan Nasional.Jakarta.Grasindo

H.A.R. Tilaar.(2004).Multikulturaisne Tantangan-tantangan Global, Yogyakarta, Bintang Pelajar.

Husaini Usman, \& Purnomo Setiady Akbar, R. 2004. Metodologi Penelitian. Sosial. Jakarta: Bumi Aksara.

Kimbal Wiles dan John T. Lovell, 1975. Supervision for Better School, New Yersey: Pritice Hall.

Maunah, Binti. "Hand Out Supervisi Pendidikan Islam," dalam http://blog.iaintulungagung.ac.id/uunbinti/2013/II/09/32/ diakses pada Jumat, 22 April 2016 pukul 20.20 WIB

Nazri, Ziria. "Pendekatan supervisi kolaboratif," dalam http://zirya.mywap blog.com/pendekatan -supervisikolaboratif.xhtml diakses pada Jumat, 22 April 2016 pukul 20.30 WIB

Sergiovanni. (1987). Educational Governance and Administration. New jersey: Prentice Hall Inc

Sugiyono, 2009, Metode Penelitian Kuantitatif, Kualitatif dan $R \& D$, Bandung : Alfabeta.

Zuriah Nuzul, 2009, Metodologi Penelitian Sosial Pendidikan Teori-Aplikasi, Jakarta: PT Bumi Aksara. 